\title{
FIRST HEXACTINELLID SPICULES FROM THE LATE CAMBRIAN OLISTOLITH, OF THE LOS SOMBREROS FORMATION, TONTAL RANGE, SAN JUAN PRECORDILLERA, ARGENTINA
}

\author{
Matilde S. BERESI' and Aldo L. BANCHIG \\ ' IANIGLA, Departamento de Paleontología CRICYT, C.C. 131, Mendoza, Argentina. \\ 2 Instituto de Geología, Universidad Nacional de San Juan. San Juan, Argentina.
}

Beresi, M. S. and Banchig, A. L. 1997. First hexactinellid spicules from the Late Cambrian olistolith, of the Los Sombreros Formation, Tontal Range, San Juan Precordillera, Argentina. Revista Española de Paleontología, 12 (2), 141-150. ISSN (2213-6937.

\begin{abstract}
A moderately diverse fauna of hexactinellid sponges is described from one Late Cambrian olistolith of the Los Sombreros Formation from Tres Saltos Gulch in the Tontal Range,Western Precordillera, San Juan Province, Argentina. Protospongia sp., Diagoniella? sp., Kiwetinokia, anchoring spicules, prodiaenes, diagonally arranged spicules and root tuft are present.

The preservation degree of the spicules and the patterns allow us to presume that after their death, they were transported not very far from the original sponges oases.

The Cambrian oolitic grainstone limestones with spicules conform an olistolith which was transported and resedimented during the Ordovician by gravity flows within a pelitic matrix of the terrigenous-carbonate talus of the Los Sombreros Formation.
\end{abstract}

Keywords: Hexactinellid spicules, Cambrian, Ordovician, Precordillera, Western Argentina.

\section{RESUMEN}

Se describe una fauna de espículas hexactinélidas de edad cámbrica superior, de moderada diversidad, procedente de la Quebrada Tres Saltos en la Sierra del Tontal, Precordillera occidental, provincia de San Juan, oeste de Argentina. En la asociación están presentes Protospongia sp., Diagoniella? sp., Kiwetinokia, prodianes, espículas ancliformes de fijación, espículas estauractinas y hexactinas con disposición diagonal y raíces (espículas basales).

El grado de preservación de las espículas y su modo de disponerse permiten interpretar que fueron depositadas cerca del oasis de esponjas original. Los grainstones oolíticos con espículas conforman un olistolito de edad cámbrica superior, el cual fue transportado y re-sedimentado durante el Ordovícico por flujos gravitatorios, en una matriz pelítica de los sedimentos terrígenos-carbonáticos del talud de la Formación Los Sombreros.

Palabras clave: Espículas hexactinélidas, Cámbrico, Ordovícico, Precordillera, oeste de Argentina.

\section{INTRODUCTION}

A new hexactinellid sponge locality was discovered in the San Juan Precordillera, in western Argentina, during fieldwork in 1994 by Banchig, from the San Juan University.

Porifera are known principally from disassociated spicules in Cambrian rocks from the Precordillera, western Argentina. The fossils described here are from the Upper Cambrian Los Sombreros Formation, in the Tres Saltos Gulch, Tontal Range in the Western Precordillera, west of San Juan city.
Protospongia was first mentioned by Rusconi (1955), by Pernas (1964), and then by Devizia (1973), from the San Isidro area in the Precordillera of Mendoza.

Heredia et al. (1987) also described hexactinellid spicules from the Upper Cambrian of the olistolith La Cruz, Empozada Formation, in the Precordillera of Mendoza. Recently Beresi and Rigby (1994) described assemblages tentatively identilied as Kiwetinokia utahensis Walcott, 1920, from latest Early Cambrian and spicules and chancelloriid sclerites from Middle Cambrian localities of the Precordillera of San Juan and Mendoza. 


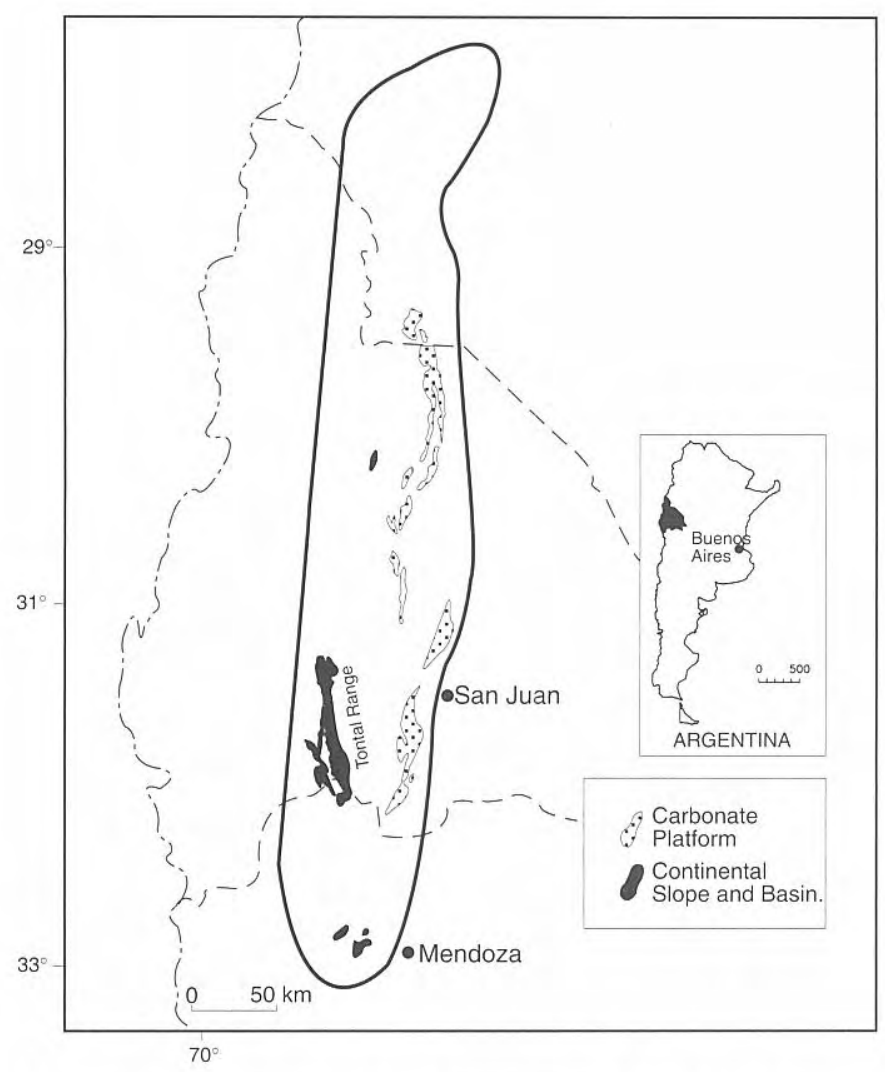

Figure 1. Location of the province of San Juan within Argentina. Map of San Juan Province showing the position of the Tontal Range in the Argentina Precordillera.

The Cambrian fauna here described was found in the peri-platform, carbonate facies where it was transported, principally as fragments. Skeletons of sponges were replaced by calcite and occur flattened on bedding planes of laminated micritic and oolitic limestones from the upper part of one of the Cambrian olistoliths of the Los Sombreros Formation (Ordovician).

The purpose of this paper is to document the first spicule assemblage known from the Upper Cambrian of the Tontal Range, Precordillera of San Juan (Fig. 1).

The Los Sombreros locality, where the homonimous formation was defined, is situated between $31^{\circ} 56^{\prime}$ and $31^{\circ} \mathrm{S}$ latitude, and the $69^{\circ} 03^{\prime}$ and $69^{\circ} 06^{\prime} \mathrm{W}$ longitude. This sector comprises the southern and eastern sector of the Tontal Range (Fig. 2).

Outcrops of the Los Sombreros Formation were first mentioned and named by Cuerda et al. (1983) when surveying for the Geological Sheet Nr. 21c San Juan. In this work the authors gave the name of Los Sombreros

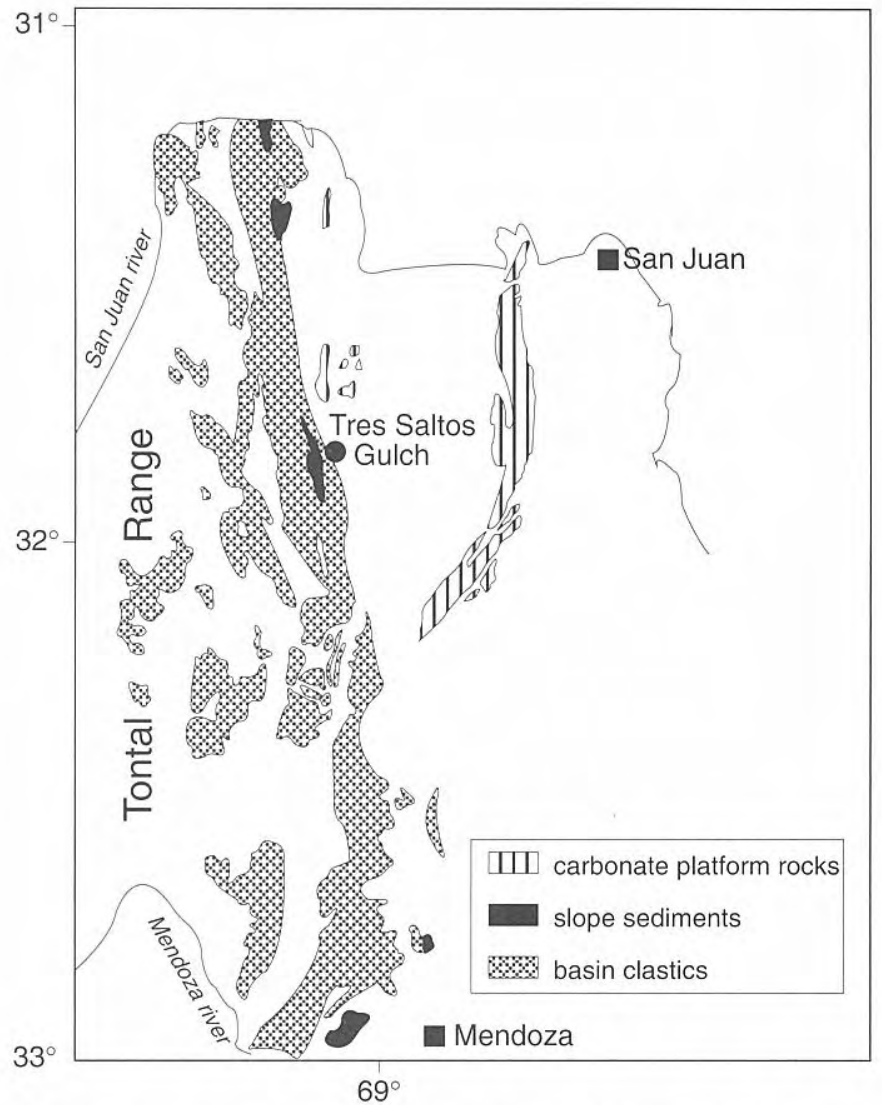

Figure 2. Distribution of Cambrian-Ordovician sediments in the Precordillera and fossil location of the Tres Saltos Gulch, Tontal Range.

Formation to a sequence formed by lutites, limestones and carbonate conglomerates. Subsequently Cuerda et al. (1985) found Cambrian sedimentary rocks at the base of the formation. Cuerda et al. (1986) analyzed the graptofaunas of the Los Sombreros Formation in the Tres Saltos and Seca gulches and established a range of age, of Tremadocian-Caradocian. The Los Sombreros Formation is a talus olistostromic sequence, composed by allochthonous carbonate blocks of Cambrian age within an autochthonous Ordovician sequence, that extends to include the rest of the talus outcrops of the western Precordillera border.

\section{GEOLOGICAL SETTING}

Sedimentary rocks from the Lower Paleozoic and the Cenozoic crop out in the Los Sombreros Gulch and have distinctive tectonic stratigraphic relationships.

\section{Plate I}

1 Protospongia sp. shows reticulated quadrules of the stauractine-based skeleton and long rayed hexactines forming marginal spines along the left margin; oscular margin is not preserved (TS 1-a).

2,3,5 Protospongia $\mathrm{sp}$. shows stauractine-based skeletons arranged in regular vertical-horizontal pattern (TS 5-a).
4 Diagoniella ? sp. diagonally oriented stauractines (TS 4-a).

6 Diagoniella? sp. anchoring spicules and hexactine with diagonal orientation (TS 3-a). 
Plate I
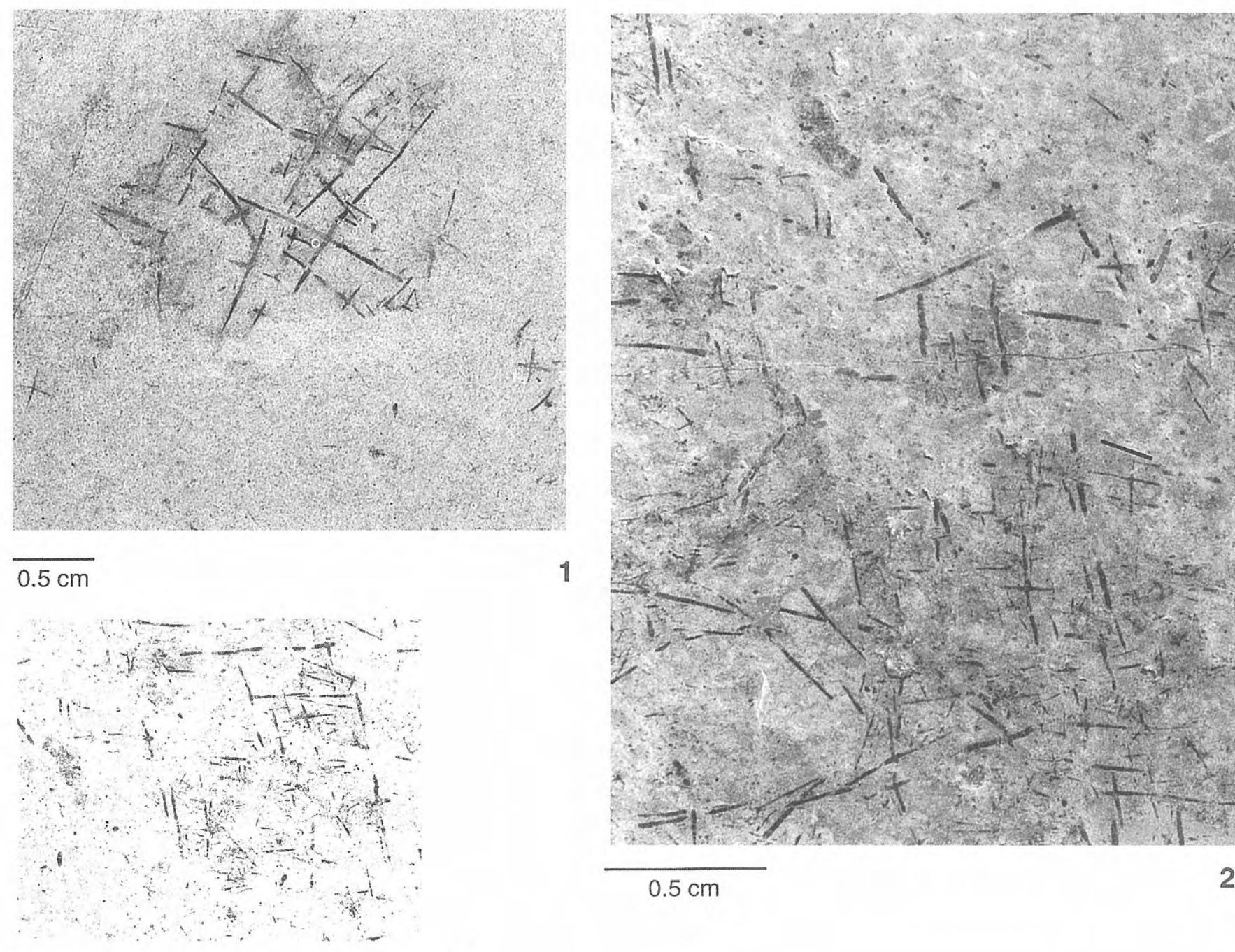

$\overline{0.5 \mathrm{~cm}}$

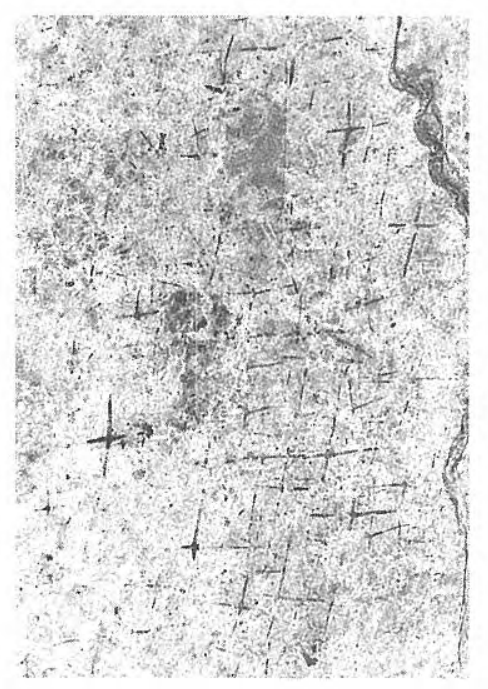

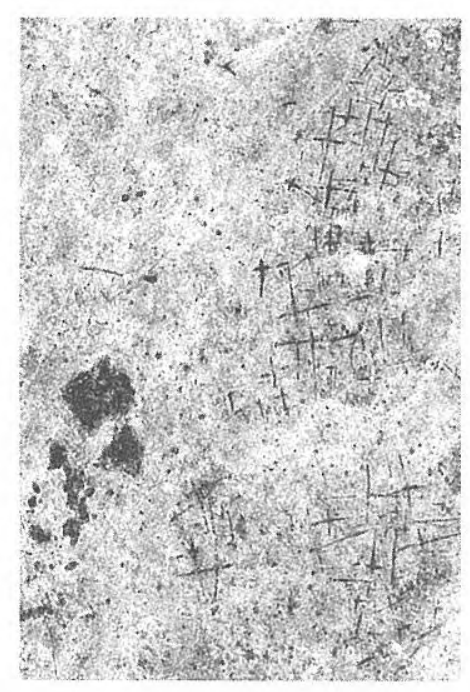

5

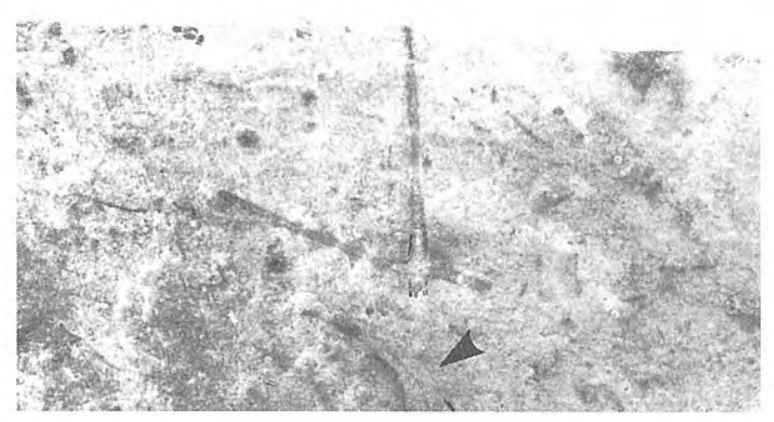

6

Revista Española de Paleontología, 12 (2), 1997. 
Continental sedimentary rocks from the Tertiary outcrop cover the eastern slope of the Tontal Range, and they are overlain by sediments of uncertain age, but with lithological characteristics similar to the Devonian sediments of Punta Negra. These units are separated by a reverse fault with a plane dipping to the west. The siliciclastic and carbonate rocks of the Los Sombreros Formation are superposed on deposits of probable Devonian age, through a reverse fault with a dip to the west. The sedimentary sequence of the Los Sombreros characterizes an olistostromic sequence, composed of authochtonous carbonate sediments of Ordovician age that enclose allochthonous carbonate blocks and olistoliths with Cambrian fossils.

The Los Sombreros Formation is limited at the base and top by high-angle reverse fractures with a regional character. These fractures are the base of the overthrusts and the eastern boundary of the Occidental Precordillera. These fractures are observed along the eastern flank of the Sierra del Tontal and the Sierra del Tigre to the north.

\section{Lithofacies descriptions}

The following lithofacies association can be found at Los Sombreros: a) mudstones, b) lutites, c) carbonate breccias, d) oolitic grainstones, e) blocks and olistoliths, (Fig.3).

A) Mudstones: They constitute tabular intercalations of fine micritic carbonates, with uniform thickness between 5 and $10 \mathrm{~cm}$ and with great lateral continuity. They are frequently associated with regular lutite intercalations. These carbonates have an abundant fossiliferous content, generally trilobites.

B) Lutites: They are dark gray to black, have good fissility and lamination, and constitute frequent intercalations in all the sequence. In some sectors they are associated with marcasite nodules and with disseminated pyrite. They constitute stratification boundaries ranging from millimeter thickness to several meters thick. They occasionally contain graptolites.

C) Carbonate breccias: They are formed of irregular lenticular bodies with eroded bases and flat tops, and are laterally continuous. They are constituted of blocks and clasts of different sizes, generally angular, with variable fabric from clast supported to matrix supported. They have coarse normal gradation and the greatest thicknesses of these megabreccias are over $20 \mathrm{~m}$, where superposition and amalgamation of several sedimentary events can be observed. Towards the top of these bodies, stratification is more evident and tabular, and the predominant structures are parallel lamination and normal gradation, until culminating at the even flat top.

D) Oolithic grainstones: This lithofacies is formed of very regular alternations of tabular strata that do not exceed $3 \mathrm{~cm}$ in average thickness. The intercalated units are very fine micritic carbonate strata of lime mudstone and oolitic grainstone. These sequences are completed by thin lutite intercalations. Over the exposures of the strata it has been possible to detect the presence of poorly preserved fossiliferous remains of trilobites and sponge spicules, including small recognizable parts of the former.

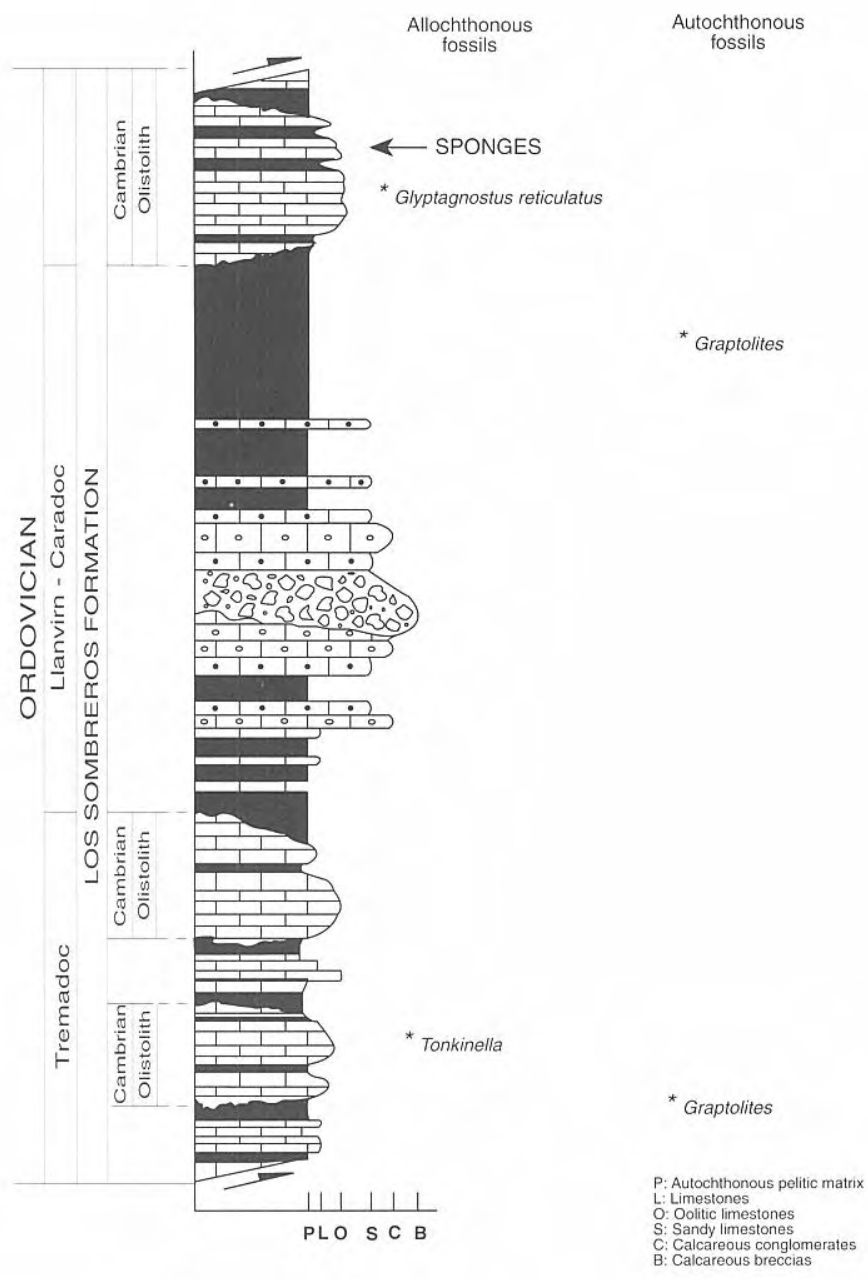

Figure 3. Generalizad stratigraphic section of the Ordovician sequence from the Tres Saltos Gulch, Tontal Range, San Juan Precordillera.

E) Blocks and Olistoliths are manifested as a carbonate compact mass with some interior sedimentary structures such as folding or brecciation. They are easily recognized for they project above the surface and show clear boundaries in all of their borders, and their sedimentary structures (stratification) show lateral continuity.

\section{Fossiliferous content}

The fossiliferous content of the Los Sombreros Formation has been studied by several authors since 1983. Cuerda et al. (1986) described and updated the age of this formation and they also defined its chronologic range as from the Tremadocian to the Caradocian, based on graptolites. The lower part of the stratigraphic profile was assigned to the Middle Cambrian because of its fossiliferous content, and was interpreted as a tectonic contact (Banchig et al., 1990).

Paleontological research done to date reveals the presence of allochthonous sediments of Cambrian age within an autochthonous Ordovician sequence. So far, the following Cambrian trilobites have been detected: Tonkinella sp., Bathyuriscus sp., Pseudagnostus sp., and Glossopleura sp. Glyptagnostus reticulatus is indicative 
Plate II

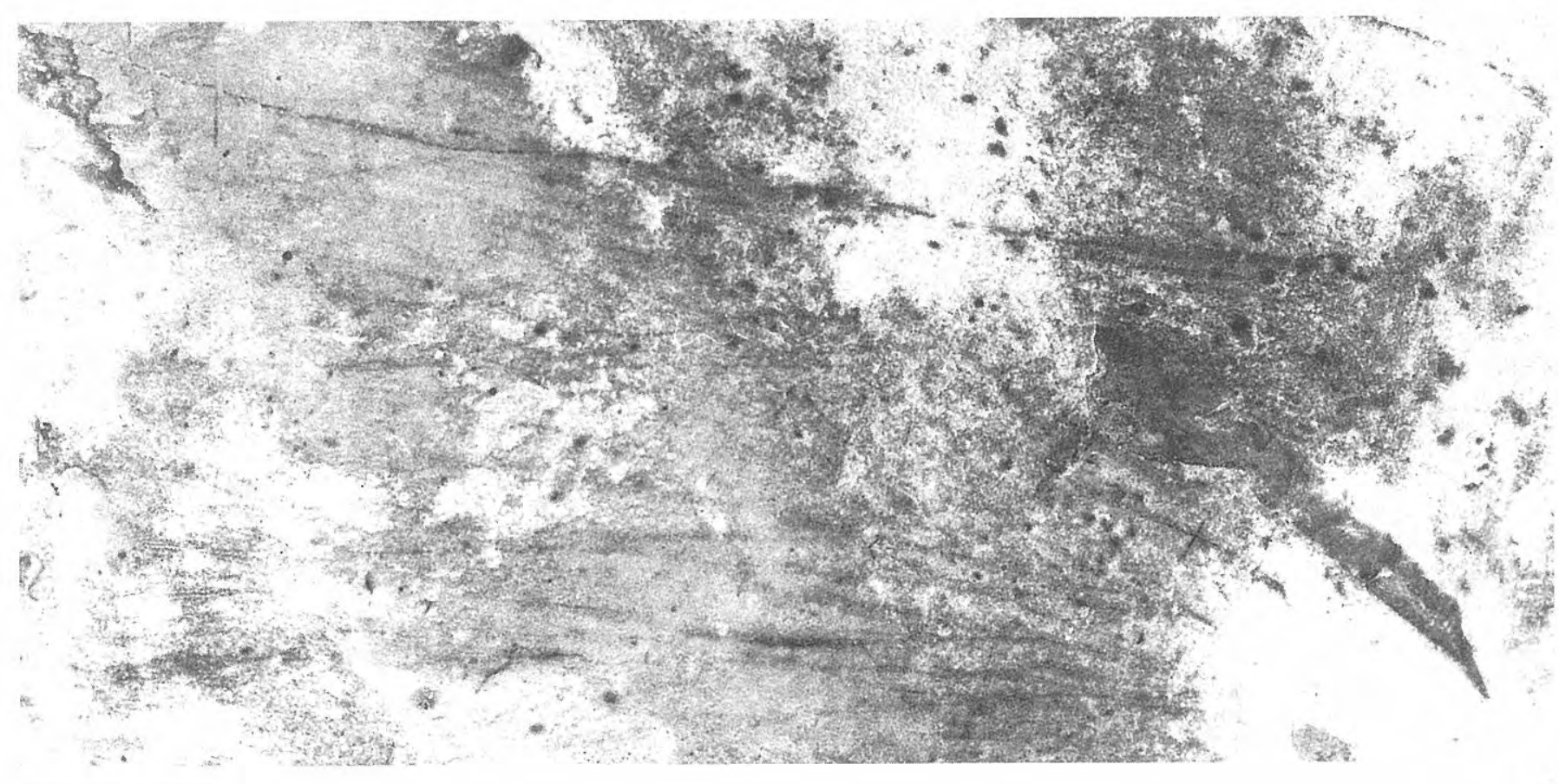

$0.5 \mathrm{~cm}$

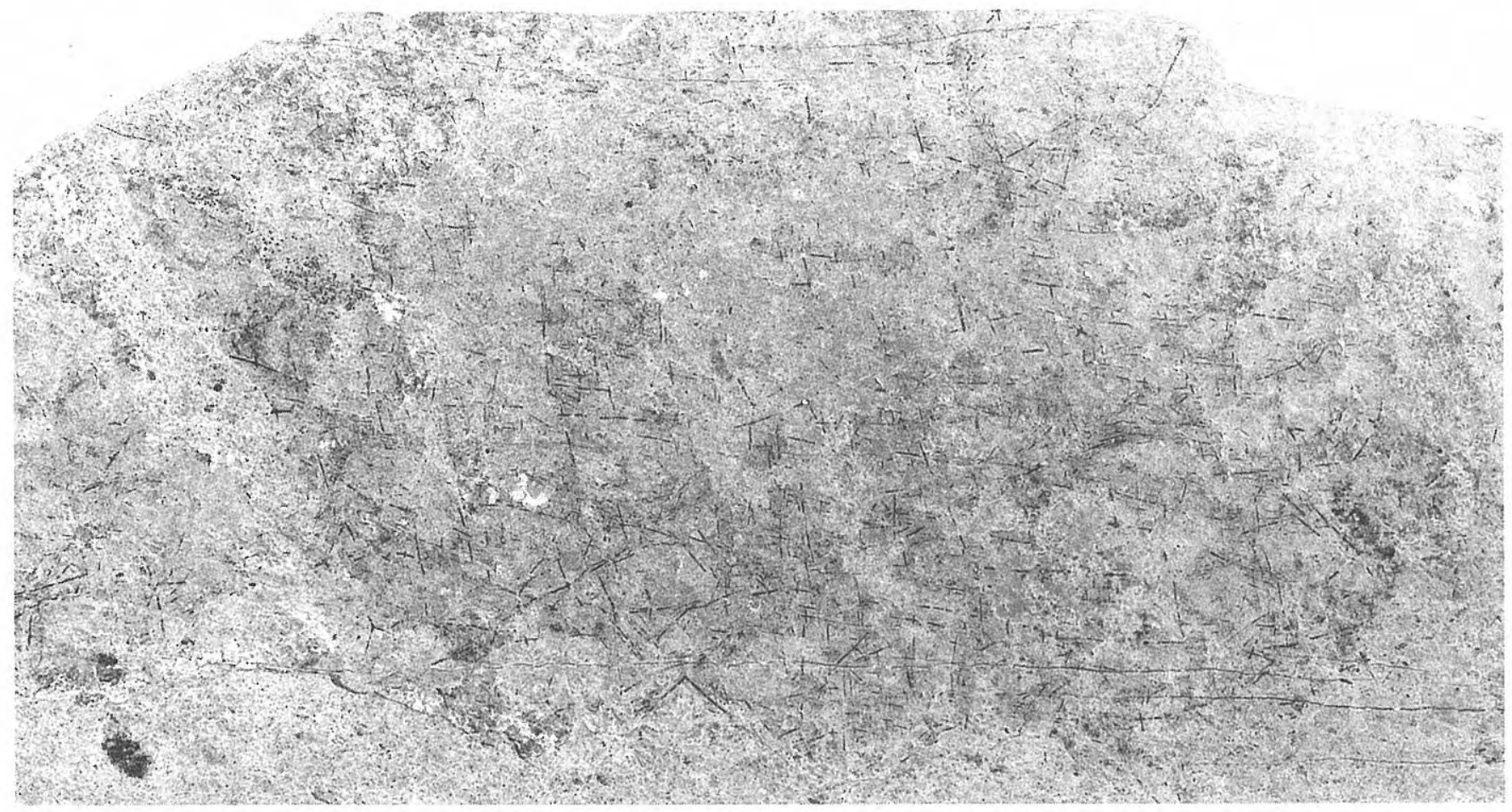

$0.5 \mathrm{~cm}$

1 Root tuft spicules associated with hexactines between tracts (TS $3 \mathrm{c}$ ).
2 Several specimens and associated spicules occur on a single bedding surface (TS 5). 
of the middle Upper Cambrian (Bordonaro and Banchig, 1990).

\section{REPOSITORY}

The collection is deposited in the Department of Geology and Paleontology of the CRICYT (Centro Regional de Investigaciones Científicas y Técnicas), Mendoza, Argentina. All material is identified as CRICYT-TS (Tres Saltos collection).

\section{SYSTEMATIC PALEONTOLOGY}

The sponges are included within the Protospongioidea because of their thin fine wall, simple spiculation, quadrangular skeletal orientation and lack of fusion of the stauract or hexactine-based spicules.

PHYLUM PORIFERA Grant, 1836

CLASS HEXACTINELLIDA Schmidt, 1870

ORDER RETICULOSA Reid, 1958

Superfamily PROTOSPONGIOIDEA Hinde, 1887

Family Protospongiidae Hinde, 1887

Genus Diagoniella Rauff, 1894

$$
\begin{aligned}
& \text { Diagoniella? sp. } \\
& \text { Pl. I, figs. } 4,6
\end{aligned}
$$

\section{Description}

The sponge body shape is unknown, only impressions of spicules are preserved.

The spicules are arranged into a ranked rectangular net, like than Diagoniella, with vertical rays at $75^{\circ}$ and $85^{\circ}$.

Spicules includes hexactines with diagonally oriented paratangential rays .

The diagonally arranged spicules have rays that range from approximately 1.90 to $6 \mathrm{~mm}$ long in the vertical rays and $1.39-1.56 \mathrm{~mm}$ to $6 \mathrm{~mm}$ long in the horizontal rays.

The skeletal fabric with only two orders of spicules distinguishable. First-order rays range from 1.39 to $6 \mathrm{~mm}$ long and basal diameters of approximately $0.25 \mathrm{~mm}$ to 0.36 $\mathrm{mm}$ and tips are $0.22 \mathrm{~mm}$. Second-order rays range from 0.8 to $1.3 \mathrm{~mm}$ long and with basal diameters of 0.14 to 0.17 $\mathrm{mm}$. The diagonally arranged rays have moderately robust basal diameters and subcylindrical in proximal parts.

The column of first-order hexactines appear superficially as stauractines, but proximal and distal rays are evident as central swellings at ray junctions of the hexactines. Nodes $(0.1 \mathrm{~mm})$ projecting from spicule ray junctions represent rudimentary or atrophied proximal-distal rays.
Scattered anchoring root spicules (Pl. I, fig. 6) are also present, with a basal diameter of $0.2 \mathrm{~mm}$ and a curved ray of approximately 2-4 $\mathrm{mm}$ long. Two Y-shaped prodiaenes are present in the association and they range from 1-2 $\mathrm{mm}$ long in vertical rays and $1 \mathrm{~mm}$ in the two paratangencial rays.

The specimen TS 4-a (Pl. I, fig. 4) is $3.10 \mathrm{~cm}$ long and has a maximum flattened incomplete width of $11 \mathrm{~mm}$, but osculum, base and lateral margins are not preserved. In a quadrule of $16.55 \mathrm{~mm}$ there are 10 spicules.

Dimensions of spicules and quadrules of Diagoniella sp., are given in Tables 1 and 2.

\begin{tabular}{|c|c|c|c|}
\hline Specimen & $\begin{array}{c}\text { First Order } \\
\text { width } \times \text { height }\end{array}$ & $\begin{array}{c}\text { Second Order } \\
\text { width } \times \text { height }\end{array}$ & $\begin{array}{c}\text { Third Order } \\
\text { width } \times \text { height }\end{array}$ \\
\hline TS 4-a & $4.23 \times 2.44$ & $1.37 \times 1.02$ & $1.02 \times 0.80$ \\
& $2.11 \times 1.69$ & $1.36 \times 1.02$ & $0.96 \times 0.81$ \\
& $1.96 \times 1.34$ & $1.21 \times 1.02$ & \\
\hline
\end{tabular}

Table 1. Dimensions of quadrule orders in Diagoniella sp., in $\mathrm{mm}$.

\begin{tabular}{|c|c|c|c|c|}
\cline { 2 - 5 } \multicolumn{1}{c|}{} & \multicolumn{2}{c|}{ First-Order } & \multicolumn{2}{c|}{ Second-Order } \\
\hline Specimen & Ray length & Basal Diameter & Ray length & Basal Diameter \\
\hline TS 2-a & & & 2.20 & \\
& 6.0 & 0.30 & $\begin{array}{l}1.90 \\
1.56\end{array}$ & 0.20 \\
& 5.4 & 0.25 & 3.0 & 0.25 \\
\hline TS 3-a & 6.0 & 0.40 & 2.8 & 0.17 \\
& 4.7 & 0.36 & 1.6 & 0.14 \\
\hline \multirow{2}{*}{ TS 4-a } & 4.2 & 0.25 & 1.3 & \\
\hline
\end{tabular}

Table 2. Dimensions of spicules of Diagoniella sp., in $\mathrm{mm}$.

\section{Material}

Two rock samples with root tuft (CRICYT TS 2 and TS 3) from the Los Sombreros Formation at the Tontal Range, in the Western Precordillera, San Juan province.

A single rock sample (CRICYT TS 4), approximately 25 x $10.5 \mathrm{~cm}$, includes four small separate fragments.

Genus Protospongia Salter, 1864

\section{Protospongia sp.}

Pl. I, figs. 1-3, 5; Pl II, fig. 2

\section{Description}

Protosponge-like stauractines occur in specimens TS 1-a, Ts 3-b, Ts 4-b and TS 5.

\section{Plate III}

1,3,4 Kiwetinokia? sp. shows irregular spiculation of associated but disarticulated spicules. Stauractines and $\mathrm{Y}$-shaped prodianes are the most distinctive spicules of the association (TS 5-d).
2 Bundle of root tuft (TS 2-b). Large monaxons or monactine-appearing spicules in bundle with small stauracts or hexacts. 
Plate III
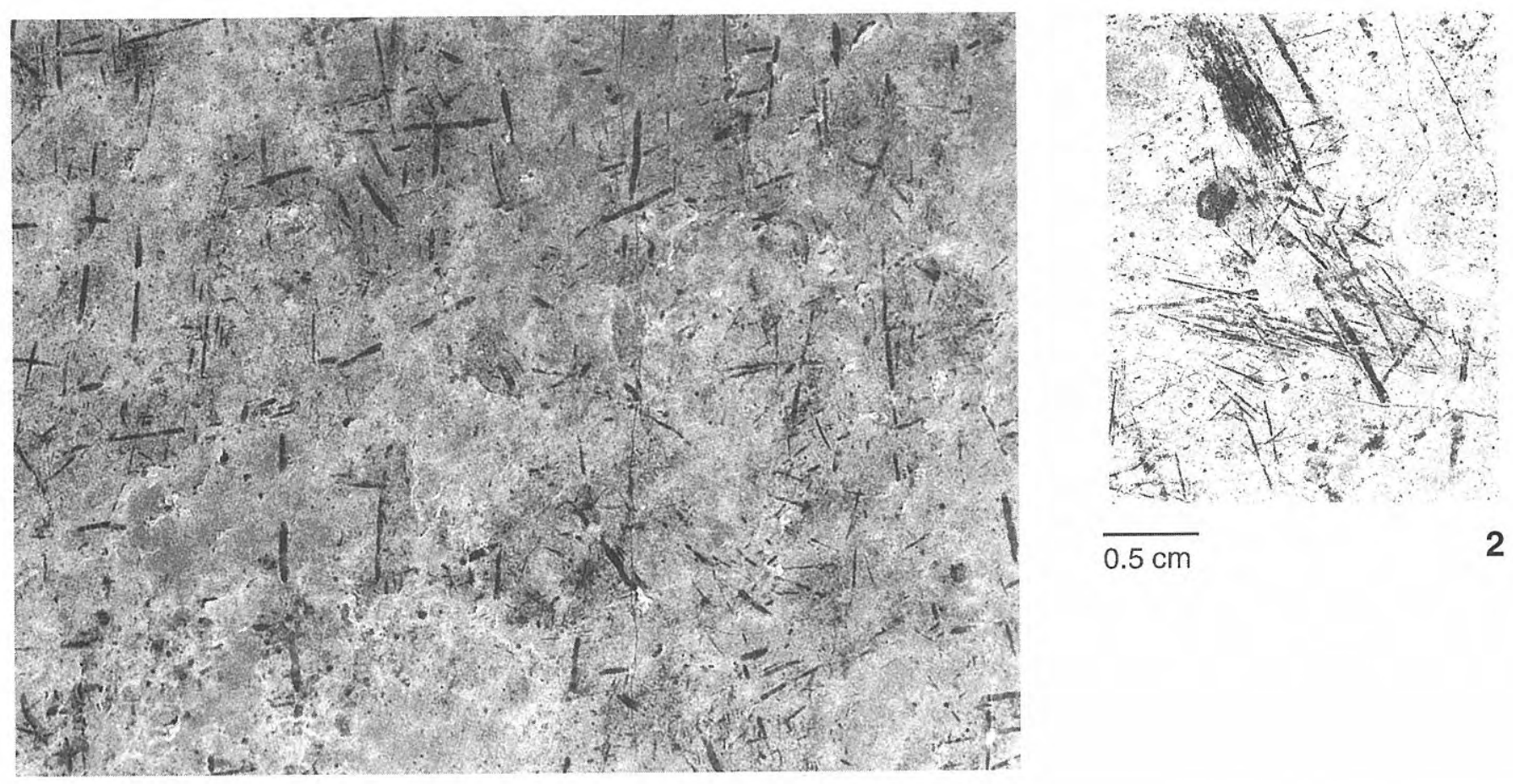

$0.5 \mathrm{~cm}$

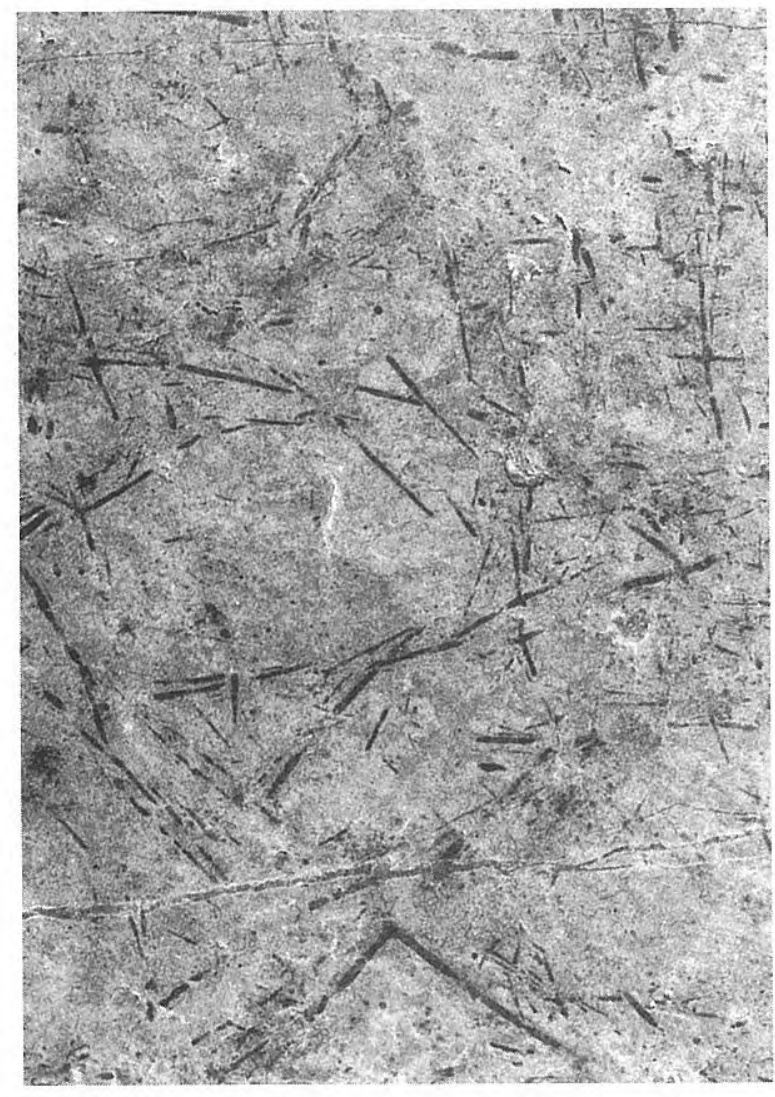

$0.5 \mathrm{~cm}$

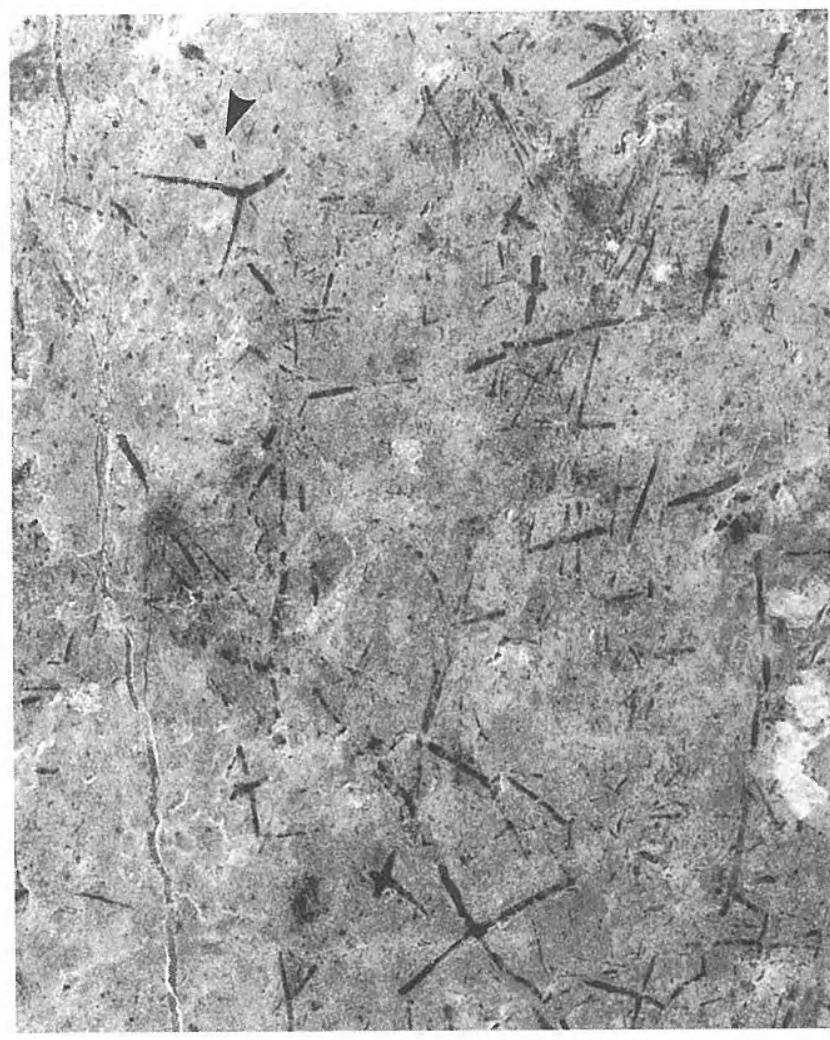

$0.5 \mathrm{~cm}$ 
Principal spicules stauractines, some with atrophied distal rays, generally arranged in regular vertical-horizontal pattern. Network quadrate, often with meshes formed principally by first- and second-order spicules. In one sample, third- or fourth-orders of stauractine can be differentiated in some specimens.

The largest specimen, TS 1-a (Pl. I, fig. 1), is a single sponge on one bedding surface, and appears to be nearly complete. The sponge body is conical-cylindrical and 17.0 $\mathrm{mm}$ high and $13.0 \mathrm{~mm}$ in maximum width. One border of the body is well preserved where spicules are lined up to define the periphery. Some marginal elongate external spicules are preserved on the periphery of the cup (marginalia?). The lower part and osculum are not visible.

At least three distinct orders of four-rayed or possibly fiveor six-rayed spicules are present. Some apparently hexactinebased spicules have projecting rudiments of atrophied distal rays. Large stauractines with rays that range from 4.0 to 5.6 $\mathrm{mm}$ long and maximum basal diameter of $0.45 \mathrm{~mm}$ represent first-order spicules of specimen TS 3-b and TS 4-b.

Second-order is defined by spicules that have rays of 1.6 to $3.2 \mathrm{~mm}$ long and basal ray diameters of $0.20-0.30 \mathrm{~mm}$, with most rays approximately $0.25 \mathrm{~mm}$ across. Other spicules include small diagonally arranged spicules. Some rays project laterally, like marginalia (TS 4-b).

The largest specimen of two sponge fragments, TS 5-a and $\mathrm{b}$ and associated spicules, on a single bedding surface, may be assigned to this genus (Pl. II, fig. 2). Possible body heights range $10-6 \mathrm{~cm}$ and $5-3.5 \mathrm{~cm}$. The incomplete preservation of the calcified fossils makes the determination of some specimens uncertain.

TS 5-a is a $10 \times 6 \mathrm{~cm}$ sponge fragment (Pl. I, figs. 2, 3, $5)$. It has a single-layered wall composed of distinctly oriented stauractines, arranged in regular vertical-horizontal pattern. The network of rectangular meshes is formed principally by first- and second-order spicules.

Two small associated specimens (TS 5-b and TS 5-c) also may be assigned to Protospongia sp.

Dimensions of spicules and quadrules of Protospongia sp. are given in Tables 3 and 4 .

\section{Material}

Numerous specimens, in varying degrees of completeness, are in the collection, CRICYT TS 1, TS 3-b, TS 4-b and TS 5. One slab includes two sponge fragments, TS $1-\mathrm{a}$, which is $1.8 \times 1.7 \mathrm{~cm}$, and TS $1-\mathrm{b}$, which is $1.4 \mathrm{x}$ $0.75 \mathrm{~cm}$, and isolated hexactines or pentactines. Several specimens and associated spicules occur on one slab (CRICYT TS-5) of $28.5 \mathrm{~cm} \times 15.5 \mathrm{~cm}$.

\section{Genus Kiwetinokia Walcott, 1920}

\section{Kiwetinokia sp. \\ Pl. III, figs. 1,3,4}

\section{Description}

The form of the sponge and the relation of these various spicules to one another is unknown. Largest specimen shows a variety of disassociated spicules which includes stauractines, Y-shaped prodiaenes and hexactines.

\begin{tabular}{|l|l|c|c|c|c|c|c|c|}
\cline { 2 - 9 } \multicolumn{1}{c|}{} & \multicolumn{2}{c|}{ First-Order } & \multicolumn{2}{c|}{ Second-Order } & \multicolumn{2}{c|}{ Third-Order } & \multicolumn{2}{c|}{ Fourth-Order } \\
\hline Specimen & $\begin{array}{c}\text { Ray } \\
\text { length }\end{array}$ & $\begin{array}{c}\text { Basal } \\
\text { Diamcter }\end{array}$ & $\begin{array}{c}\text { Ray } \\
\text { Length }\end{array}$ & $\begin{array}{c}\text { Basal } \\
\text { Diameter }\end{array}$ & $\begin{array}{c}\text { Ray } \\
\text { length }\end{array}$ & $\begin{array}{c}\text { Basal } \\
\text { Diameter }\end{array}$ & $\begin{array}{c}\text { Ray } \\
\text { Length }\end{array}$ & $\begin{array}{c}\text { Basal } \\
\text { Diameter }\end{array}$ \\
\hline TS 1-a & 1.70 & 0.16 & 0.34 & 0.05 & & & & \\
& & 0.15 & 0.68 & 0.09 & & & & \\
\hline TS 1-b & 9.11 & 0.41 & 4.38 & 0.25 & 2.75 & 0.27 & 1.29 & 0.11 \\
& 7.18 & 0.24 & & & 2.02 & 0.37 & 0.19 & 0.05 \\
& 5.01 & 0.21 & & & & & & \\
\hline TS 4-b & 1.98 & 0.25 & 1.36 & 0.17 & 0.96 & 0.11 & & \\
& & & 1.16 & 0.14 & & & & \\
\hline TS 5-a & 1.64 & 0.21 & 0.51 & 0.10 & & & & \\
& 1.61 & 0.19 & 0.31 & 0.07 & & & & \\
\hline
\end{tabular}

Table 3. Dimensions of spicules of Protospongia sp., in $\mathrm{mm}$.

\begin{tabular}{|c|c|c|c|}
\hline Specimen & $\begin{array}{c}\text { First Order } \\
\text { width } \times \text { height }\end{array}$ & $\begin{array}{c}\text { Second Order } \\
\text { width } \times \text { height }\end{array}$ & $\begin{array}{c}\text { Third Order } \\
\text { width } \times \text { height }\end{array}$ \\
\hline TS 1-a & $4.59 \times 3.73$ & $3.62 \times 2.67$ & $0.50 \times 0.35$ \\
& $4.67 \times 3.16$ & $3.74 \times 2.62$ & $0.65 \times 0.35$ \\
& $\begin{array}{c}3.90 \times 4.34 \\
3.23 \times 2.98\end{array}$ & & \\
& $3.42 \times 3.21$ & & \\
& $3.92 \times 3.31$ & & \\
& 3.57 .42 & & \\
\hline TS 1-b & $2.34 \times 2.16$ & $1.98 \times 1.25$ & \\
& $2.00 \times 1.72$ & & \\
& $2.05 \times 1.51$ & & \\
& $1.43 \times 1.01$ & & \\
\hline TS 5-a & $3.56 \times 2.15$ & $1.84 \times 1.59$ & \\
& $2.46 \times 2.44$ & & \\
\hline TS 5-b & $0.97 \times 0.57$ & $0.59 \times 0.44$ & \\
& $0.68 \times 0.57$ & $0.45 \times 0.34$ & \\
& $0.54 \times 0.52$ & & \\
& $0.58 \times 0.58$ & & \\
\hline
\end{tabular}

Table 4. Dimensions of quadrule orders in Protospongia sp., in $\mathrm{mm}$.

In the specimen TS 5-d, there are some Y-shaped spicules which Walcott (1920) referred to as prodiaenes, some of the most distinctive spicules of genus Kiwetinokia. The largest cruciform spicules, the stauractines, have rays 5 to $2 \mathrm{~mm}$ long; smaller spicules generally have rays 1.0 to 0.5 $\mathrm{mm}$ long. Prodiaenes have rays 4 to $2 \mathrm{~mm}$ long. Hexactines are less common, ray lengths of spicules range from 1 to 4 $\mathrm{mm}$ and nodes of $0.4-0.1 \mathrm{~mm}$.

\section{Material}

One slab ( TS 5-d) is in the collection, showing a mass of intermingled stauractine, triactine and spicule fragments.

\section{ROOT TUFT}

Pl. II, fig. 1; Pl. III, fig.2

\section{Description}

A bundle of root tuft and isolated spicules occur on the bedding plane of the specimen TS 2-b. Large monaxons or monactine-appearing spicules occur in a bundle. Small 


\begin{tabular}{|c|c|c|c|}
\hline Specimen & Ray length & Ray diameter & Diameter of corone \\
\hline TS 2-b & $43-18$ & 0.50 & $2.8 \times 2.7$ \\
& & 0.01 & $14 \times 13$ \\
\hline TS 3-c & $50-30$ & 0.36 & \\
& & 0.22 & \\
\hline
\end{tabular}

Table 5. Dimensions of root tuft in $\mathrm{mm}$.

stauracts or hexacts occur on and in between the tuftspicules (Pl. III, fig. 2). The central disc of the specimen has a diameter of $2.8 \mathrm{~mm} \times 2.7 \mathrm{~mm}$.

The tuft pieces are broken at both ends, thus it cannot be determined whether the spicules are diactines or monoactines. The incompletely preserved spicules were originally longer. The figured specimen is a tuft with coarse and fine radiating coronal spicules that extend out some distance from the margin of the central disc. Individual coarse spicules are about 17, 14.5, and $11 \mathrm{~mm}$ long and have a diameter of $0.50 \mathrm{~mm}$. Fine spicules in the complex have diameters of $0.01 \mathrm{~mm}$ to $0.05 \mathrm{~mm}$.

In addition to the long spicules, smaller triaxons, hexacts, stauracts, and anchoring spicules are associated with the variety of Y-shaped prodiaenes. These spicules are scattered over and outside the tuft, and it is not certain that they really belong to the sponge.

In the specimen TS 3-c (Pl. II, fig. 1) the central disc of radiating spicules has a diameter of approximately $14 \mathrm{~mm}$.

Two root tufts of bundled spicules are the most prominent skeletal features. The two vertical bundled tracts are composed of up to 8 rays of diactines (?) $50 \mathrm{~mm}$ long. Most radiating coronal spicules extend approximately 30 $\mathrm{mm}$, but some reach a maximum of $50 \mathrm{~mm}$ beyond the illdefined edge of the disc. Coronal spicules are smooth and taper in both directions, which may indicate an apparent diactine nature of root spicules in the described specimen. Some hexactines occur between tracts, few isolated diagonally-arranged spicules and stauractine are present outside the tuft. Two anchorate spicules are also present. They are gently curved and very long $(4 \mathrm{~mm})$ and probably reached beyond the original membrane of the sponge. Dimensions of root tufts are given in Table 5.

\section{Material}

The described and figured spicules occur on mudstone samples CRICYT TS 2-b and TS 3-c, Tres Saltos Gulch, Tontal Range.

\section{PALEOECOLOGICAL IMPLICATIONS}

In terms of ecology, the early hexactinellids in the Cambrian seem to have inhabited a variety of lowenergy, relatively deep water settings with soft bottoms that may have been necessary because of their delicate construction.

Siliceous sponges become fairly widespread in quiet waters, offshore marine environments in China, Australia, Siberia and North and South America.

The Precordillera spicule fauna bears similarities to assemblages from Laurentia but lacks representatives of the Calcarea, presumably because this fauna lived in a deeper water setting.

The fossil record of siliceous sponges is known in the Precordillera, based mainly on disarticulated spicules and scattered, poorly preserved, body fossils. Spicules recovered from the Middle and Upper Cambrian strata in the Precordillera, indicate abundance of early hexactinellid sponges.

In fossil assemblages from the Precordillera, the genera Protospongia, Kiwetinokia and Diagoniella are moderately common and occur on the bedding plane of the lime-wackestones. The samples have not monospecific sponge assemblages. Calcification of the spicules can be related to a local rise of the $\mathrm{pH}$ level in the decayed sponge.

Principal spicules appear superficially as stauractines but proximal and distal rays are frequently evident as small central swellings in the ray junctions of the hexactines. Nodes represent rudimentary or atrophied proximal-distal rays, but well-developed paratangential rays give rise to stauractinelike appearance of spicules, Mehl et al. (1993).

This sponge association can be interpreted as a relict of a single community that grew on a low-energy, normal marine salinity, and stable marly to silty sea floor. The presence of anchoring spicules suggests that some of the sponges were attached to the substrate with these specialized spicules and root tufts, and thus, they probably lived in moderately quiet though occasionally turbulent enviromenment. They had stalks to keep them well above the sediment. Others sponges did not have root tufs. For example, Melh et al. (1993) suggest that Diagoniella nevadensis Rigby and Stuart, 1988 probably settled with their bases partly buried in sediment and forms such as Protospongia conica Rigby and Harris, 1979 do have root tufts.

The preservation of most specimens suggests that they were gently transported and buried not far from the "oases" of occupation, probably in a continental shelf margin (periplatform environment). During the Ordovician, when the shelf margin collapsed, the calcareous blocks with Cambrian sponges, were transported to their final deposition and burial, by gravity flows, within a pelitic matrix of the terrigenous-carbonate slope.

The Cambrian sediments of the Precordillera yield fossil spicules that indicate abundance of siliceous sponges as part of the Cambrian "explosion".

\section{ACKNOWLEDGMENT}

We thank the referees for their critical comments which improved this paper and specially to Dr. J.K. Rigby's detailed reviews on the manuscript.

\section{BIBLIOGRAPHY}

Banchig, A.L., Keller, M. y Milana, J. 1990. Brechas calcáreas de la Formación Los Sombreros, Quebrada 
Ojos de Agua, Sierra del Tontal, San Juan. Actas XI Congreso Geológico Argentino, San Juan, 2, 149-152.

Beresi, M. and Rigby, J.K. 1994. Sponges and chancelloriids from the Cambrian of western Argentina. Journal of Paleontology, 68, 208-217.

Bordonaro, O. y Banchig A. 1990. Nuevos Trilobites del Cámbrico en la Quebrada Ojos de Agua, Sierra del Tontal, San Juan, Argentina. Actas V Congreso Argentino de Paleontología y Bioestatigrafía, Correlación Geológica, 7, 32-38.

Cuerda, A.J., Cingolani, C. y Varela, R. 1983. Las graptofaunas de la Formación Los Sombreros, Ordovícico inferior de la vertiente oriental de la Sierra del Tontal. Ameghiniana, 20(3-4), 239-260.

Cuerda, A.J., Schauer, O.C. y Varela, R. 1985. El Ordovícico de la Sierra del Tontal, Precordillera de San Juan. Actas VI Congreso Geológico Chileno, Antofagasta, Chile, 190-192.

Cuerda, A.J., Cingolani, C., Varela, R. y Schauer, O. 1986. Cámbrico y Ordovícico en la Precordillera de San Juan: Formación Los Sombreros, ampliación de su conocimiento bioestratigráfico: IV Congreso Argentino de Paleontología y Bioestratigrafía, Mendoza, Argentina, 1, 5-17.
Devizia, C. 1973. Estudio geológico del sector de San Isidro. Departamento Las Heras, Mendoza. Tesis doctoral inédita, Museo de La Plata, $\mathrm{N}^{\circ} \mathbf{3 1 9}, 88 \mathrm{pp}$.

Heredia, S., Bordonaro, O.L. y Matteoda, E. 1987. Espículas de poríferos de la Formación La Cruz, Cámbrico Superior, Departamento Las Heras, Provincia de Mendoza. Ameghiniana, 24(1-2), 17-20.

Mehl, D., Rigby, J.K. and Holmes, S. 1993. Hexactinellid sponges from the Silurian-Devonian Roberts Mountains Formation in Nevada and hypotheses of hexactinestauractine origin. Brigham Young University, Geology Studies, 39, 101-124.

Pernas, D. 1964. El género Protospongia en el Cámbrico de Mendoza. (Resumen). $2^{a}$ Reunión de Comunicaciones Científicas de la División Geología de la Facultad de Ciencias Naturales y Museo La Plata. Miscelánea, 1, 3-4.

Rusconi, C. 1955. Fósiles cámbricos y ordovícicos al oeste de San Isidro, Mendoza. Revista del Museo de Historia Natural de Mendoza, 8(1-4), 3-64.

Walcott, C.D. 1920. Middle Cambrian Spongiae. Smithsonian Miscelanea Collection, 67, 261-364.

Manuscrito recibido: 29 de abril, 1996 Manuscrito aceptado: 25 de noviembre, 1996 